九州大学学術情報リポジトリ

Kyushu University Institutional Repository

\title{
Impact of Agricultural Subsidy Policies on Grain Prices in China
}

Qian, Jiarong

Institute of Agricultural Economics and Development, Chinese Academy of Agricultural Sciences

Ito, Shoichi

Department of Agricultural and Resource Economics, Faculty of Agriculture, Kyushu University : Professor

Zhao, Zhi jun

Institute of Agricultural Economics and Development, Chinese Academy of Agricultural Sciences

Mu, Yueying

College of Economics and Management, China Agricultural University

他

https://doi.org/10.5109/1526325

出版情報: 九州大学大学院農学研究院紀要. 60 (1)，pp.273-279，2015-02-27. Faculty of Agriculture, Kyushu University

バージョン :

権利関係 : 


\title{
Impact of Agricultural Subsidy Policies on Grain Prices in China
}

\author{
Jiarong QIAN ${ }^{1}$, Shoichi ITO ${ }^{2}$, Zhijun Zhao ${ }^{1}$, Yueying MU $^{3}$ and Lingling $\mathrm{HOU}^{4 *}$ \\ ${ }^{1}$ Institute of Agricultural Economics and Development, Chinese Academy of Agricultural Sciences, \\ Beijing 100081, P.R. China \\ ${ }^{2}$ Department of Agricultural and Resource Economics, Faculty of Agriculture, \\ Kyushu University, Fukuoka 812-8581, Japan \\ ${ }^{3}$ College of Economics and Management, China Agricultural University, \\ Beijing 100083, P.R. China \\ ${ }^{4}$ Center for Chinese Agricultural Policy, Institute of Geographic Sciences and Natural Resources Research, \\ Chinese Academy of Sciences, Beijing 100101, P.R. China \\ (Received October 31, 2014 and accepted November 14, 2014)
}

\begin{abstract}
On the background of extensive government interventions in grain markets and the direct-payment schemes of subsidy policies, the subsidy policies may hardly show negative impacts on grain prices through increasing grain supply. In this study, we investigate the relationship between China's agricultural subsidy policies and market prices for grain and construct autoregressive distributed lag (ARDL) models to evaluate the impacts of agricultural subsidies on grain prices. The estimated results indicate that the subsidy variable is highly significant in the grain-price model for each grain type, while the general impacts of subsidies are positive. This suggests that agricultural subsidy policies contribute to increases in market prices for grain. Statistically, the overall elasticities of subsidies to the prices of rice, wheat, and corn are 0.077, 0.094, and 0.180 , respectively. Both the theoretical and empirical analyses suggest that these subsidies show positive rather than negative impacts on grain market prices under the current situations in China.
\end{abstract}

Key words: subsidy policy, grain prices, impact, autoregressive distributed lag model (ARDL)

\section{INTRODUCTION}

Since China's economy realized tremendous growth during the beginning of 2000s, large-scale funding supports became available for agriculture. At that time, China was facing a situation of decreasing grain production. As a result, in 2003, a series of agricultural subsidies was introduced, which were paid to farmers under the guideline of "offering more, taking less and loosening control." The aim of these subsidies was to mobilize farmers' enthusiasm for agricultural production, thus enabling grain production to rebound. In January 2005, to further consolidate the foundation of agriculture and increase the income of farmers, the central government decided to increase its efforts in carrying out its subsidy policy. In the political document "Opinions on a Number of Policies for Strengthening Rural Work and Raising the Overall Production Capacity of Agriculture" released in 2005, the Communist Party of China's Central Committee and the State Council emphasized that these effective policies should remain unchanged, the benefits given to farmers should not be reduced, and the support offered to agriculture should be continuously increased (China

Institute of Agricultural Economics and Development, Chinese Academy of Agricultural Sciences

${ }^{2}$ Department of Agricultural and Resource Economics, Faculty of Agriculture, Kyushu University

College of Economics and Management, China Agricultural University

${ }^{4}$ Center for Chinese Agricultural Policy, Institute of Geographic Sciences and Natural Resources Research, Chinese Academy of Sciences

* Corresponding author (E-mail: llhou.ccap@igsnrr.ac.cn)
Agricultural Development Report, 2006).

Since 2003, agricultural subsidies have included the fine-seed subsidy, direct grain subsidies, farm-machinery subsidies, and comprehensive subsidies. The fine-seed subsidy was the first subsidy. It went into force in 2003, had a value of 0.3 billion yuan, was paid out for wheat, and aimed to encourage farmers to enhance both grain yields and quality by using fine seeds. In 2004, the total subsidy amount jumped to 14.52 billion yuan; of this, the central government allocated 11.6 billion yuan from the grain-risk fund to provide direct subsidies to grain farmers who planted rice, wheat, or corn in the main producing areas. Moreover, in 2004, to increase the level of mechanization in agriculture, certain amounts of subsidies were provided to farmers for purchasing or updating large farm machinery and tools.

Given that the prices of agricultural inputs have remained high, grain production costs rose by a large margin in recent years. In the absence of subsidies, this would have had certain adverse effects on the earnings of grain farmers. To strengthen the support of central finances to agricultural development and to offset farmers' burden in the extra payments made for the purchase of diesel, fertilizer, and other inputs because of the increasing prices of these materials, a new comprehensive direct subsidy was set up in 2006 for the purchase of goods used in agricultural production. In addition, innovations were introduced to the mechanism for providing subsidies to grain production, and an amount of 12 billion yuan was paid by the central government as comprehensive subsidies to grain farmers. The total subsidy amount was increased to 30.95 billion yuan in 2006, up $78.2 \%$ over the total amount in 2005. 
Table 1. Changes in subsidy amounts from 2003 to 2012 (billion yuan)

\begin{tabular}{cccccc}
\hline Year & Fine seed subsidy & $\begin{array}{c}\text { Grain direct } \\
\text { subsidy }\end{array}$ & $\begin{array}{c}\text { Farm machinery } \\
\text { subsidy }\end{array}$ & $\begin{array}{c}\text { Comprehensive } \\
\text { subsidy }\end{array}$ & Total subsidies \\
\hline 2003 & 0.30 & - & - & - & 0.30 \\
2004 & 2.85 & 11.60 & 0.07 & - & 14.52 \\
2005 & 3.87 & 13.20 & 0.30 & - & 17.37 \\
2006 & 4.15 & 14.20 & 0.60 & 12.00 & 30.95 \\
2007 & 6.66 & 15.10 & 2.00 & 27.60 & 51.36 \\
2008 & 12.34 & 15.10 & 4.00 & 71.60 & 103.04 \\
2009 & 19.85 & 15.10 & 13.00 & 71.60 & 119.55 \\
2010 & 20.40 & 15.10 & 15.50 & 71.60 & 122.60 \\
2011 & 22.00 & 15.10 & 17.50 & 83.50 & 138.10 \\
2012 & 22.40 & 15.10 & 21.50 & 107.80 & 166.80 \\
\hline
\end{tabular}

Source: China Agricultural Development Report 2004-2013.

In 2008, both the scope and size of comprehensive subsidies were greatly expanded. Total subsidies increased to 103.04 billion yuan that year, a sizable jump of 51.68 billion or $100.6 \%$ from 2007 . That year, the central finance increased the amount paid out in comprehensive subsidies to 71.6 billion yuan. These strong measures were intended to minimize the adverse effects of price increases on agricultural production and farmers' incomes caused by the drastic rises in prices of agricultural inputs. These measures continued, and the total amount of agricultural subsidies reached a historical height of 166.8 billion yuan in 2012 (Table 1).

Since the implementation of the agricultural subsidy policy, the effects of these subsidies have attracted extensive attention from both academics and policy makers. Numerous studies have been performed to assess the effects of subsidies on agricultural production. For example, Wang and Xiao $(2006,2007)$ investigated the data of 5 counties in China and employed the positive mathematical programming model to examine the effects of agricultural subsidies on grain production and agricultural income. They concluded that the impact of the subsidy policy on grain production was not large. Jiang and $\mathrm{Wu}$ (2009) performed a field survey of farmers in Hunan Province for 2004-2008. They found no significant increase in grain planted areas when the subsidy policy was implemented during that period. Liu (2010) employed both a logit model and a multi-regression model and used survey data in Jiangxi Province to examine the influence of the subsidy policy on farmers' grain-planting decisions. The empirical results indicated that the subsidy policy stimulated an enthusiasm for the grain production of farmers whose main income relied on grain planting. Liu (2010) also found that to a certain extent, subsidies influenced an expansion of the area in which grain was planted. Chen et al. (2010) empirically analyzed the impact of subsidies on grain production, based on the provincial panel data from 2004 to 2007. They concluded that the agricultural subsidy policy could show a positive influence on grain production by affecting the planted areas and the input capital. Huang et al. (2011) used descriptive and multiple regression analysis, based on panel data in 6 provinces from 2004 to 2008, to evaluate the effects of agricultural subsidies on agricultural production. They concluded that the subsidies showed no impacts on either grain production or area planted. Mu and Koike (2009) built a SCGE model to simulate the impacts of the agricultural subsidy policy on both agricultural and non-agricultural sector outputs. Their results suggested that agricultural subsidies promoted the outputs of both the agricultural and non-agricultural sectors, but that income levels did not change much after the implementation of the subsidy policy. Zhou et al. (2009) analyzed the effects of China's agricultural support policies on the growth of grain output employing the GTAP model. Their results suggested that the subsidy policy showed a significant influence on grain production, with actual increases in the production of rice, wheat, and corn of $1.16 \%, 2.52 \%$, and $5.2 \%$, respectively.

For studies on the impacts of subsidies on grain prices, Qian et al. (2013) used co-integration techniques and the Granger causality test to examine the relationship between agricultural subsidies and rice prices. Their results indicated that the subsidy policies could have been the cause of the resulting changes in rice prices. They also found that the impact of subsidies on rice prices may be positive. Li (2013) also emphasized that agricultural subsidies showed two side effects on grain prices; one side effect was the subsidy showing a negative impact on grain prices through promoting grain production and an increased supply and the other side effect was a positive impact on grain prices through increasing grain production costs. Li also reported that agricultural subsidies are an important factor in driving up agricultural commodity prices (Li, 2011a; Li, 2011b).

Previous studies mainly focused on the impacts of subsidies on increasing agricultural outputs and farmers' income. However, few studies have empirically and deeply examined the impacts of agricultural subsidies on grain prices. In this study, we attempt to explore the impact mechanism of the subsidy policies on grain prices 
and estimate their effect on the prices.

\section{AGRICULTURAL SUBSIDIES AND GRAIN PRICES IN CHINA}

According to the basic theory of supply and demand, providing subsidies to the agricultural sector will increase grain production and push down grain prices; but one of the presuppositions is that there is no government intervention in the grain market. Similar to other countries, the Chinese government extensively intervenes in the grain market because of the importance of grain as a staple food to the huge Chinese population. In 2004, the Chinese government implemented the grain minimum purchasing price policy and has maintained this policy ever since. This policy sets a minimum purchasing price each year for each grain type. Moreover, if the market prices of grain are below their respective minimums, the government purchases the price-depressed grain from the market at the minimum price until the market prices rise above the minimum price. This policy can offset the negative impact of subsidies on grain prices. The mechanism is illustrated in Figure 1.

In Figure 1, assume that $P_{0}$ is the minimum price set by the government and that the grain market realizes equilibrium at $E_{0}$. As subsidies result in an increase in

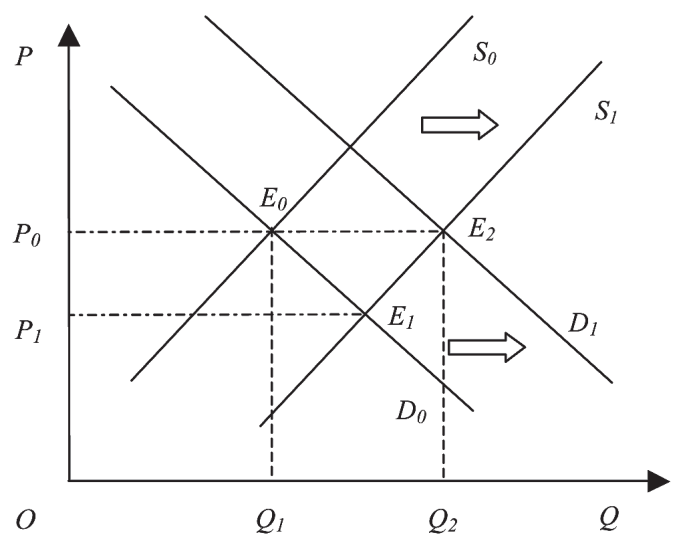

Fig. 1. Changes in the grain market with government interventions. grain production, the grain supply curve will shift from $S_{0}$ to $S_{1}$, the grain market price will decrease from $P_{0}$ to $P_{1}$, and the market will achieve equilibrium at $E_{1}$. However, because of the existence of the grain minimum purchasing price policy, the market price would not decrease to $P_{1}$. As the price tends to decrease below the minimum price, the government enters the market and purchases the grain. This intervention behavior may work in the same manner as an increase in the demand for grain, and the demand curve for grain may shift from $D_{0}$ to $D_{l}$. Finally, the market prices of grain may still remain at or above the minimum price. Therefore, the subsidy policies cannot show significantly negative influences on market prices for grain or the negative effects of the subsidy policies may be very limited. This argument can be verified if we find convincing evidence that production cannot influence grain prices.

To verify our deduction and empirically examine the influencing direction between grain prices and grain production, the Granger Causality Test $^{5}$ (Granger, 1980; Granger, 1988; Sims, 1972; Robert and Daniel, 2010) was employed to determine whether grain prices cause changes in grain production, whether grain production causes changes in grain prices, or whether prices and production influence each other in China. Three grain crops such as rice, wheat, and corn were selected for the test. For checking the homogeneity of the tests, 2-year and 4-year lags were selected. The results of the causality test are reported in Table 2. From the results, the null hypothesis $\mathrm{H}_{1}$ that grain prices do not cause changes in grain production was strongly rejected in both the cases of the 2-year and 4-year lags for each grain type at a $1 \%$ or $5 \%$ significance level. This suggests that the tests are not sensitive to the choice of lag length and indicates that grain price is a factor that causes grain production to change. Whereas hypothesis $\mathrm{H}_{2}$ that grain production does not cause grain prices to change cannot be rejected in the two cases for each grain type; this implies that grain production is not a factor causing grain prices to change, namely, grain production cannot negatively impact market prices for grain.

Table 2 reveals that in China, grain prices may cause grain production to change, rather than that production

Table 2. Granger causality test for grain price and grain production

\begin{tabular}{|c|c|c|c|c|c|}
\hline & \multirow{2}{*}{ Null } & \multicolumn{2}{|c|}{ Lag=2, N=19(1992-2012) } & \multicolumn{2}{|c|}{$\mathrm{Lag}=4, \mathrm{~N}=17(1994-2012)$} \\
\hline & & $\mathrm{F}(2,12)$ & Prob. & $\mathrm{F}(4,8)$ & Prob. \\
\hline \multirow{2}{*}{ Rice } & H1:Price $\neq>$ Production & 10.78 & 0.001 & 6.37 & 0.008 \\
\hline & H2:Production $\neq>$ Price & 0.97 & 0.399 & 1.29 & 0.338 \\
\hline \multirow{2}{*}{ Wheat } & H1:Price $\neq>$ Production & 12.56 & 0.001 & 8.69 & 0.003 \\
\hline & H2:Production $\neq>>$ Price & 0.18 & 0.836 & 3.09 & 0.067 \\
\hline \multirow{2}{*}{ Corn } & H1:Price $\neq>$ Production & 10.17 & 0.001 & 3.58 & 0.046 \\
\hline & $\mathrm{H} 2$ :Production $\neq>$ Price & 2.00 & 0.167 & 1.21 & 0.366 \\
\hline
\end{tabular}

Source: Authors' estimation.

${ }^{5}$ This Granger Causality Test follows Robert and Daniel (1998). For details, see Robert S. Pindyck. and Daniel L. Rubinfeld. (1998) Econometric Models and Economic Forecasts (4th edition), China Machine Press, pp. 242-245. 
being the cause of a change in prices. If grain production does not significantly influence market prices for grain, subsidies are expected to not have a negative influence on grain prices in the context of the political interventions in China. This provides evidence for our analysis reported in the previous section.

Such large-scale subsidies and their rapid growth in terms of their amount must show a large influence on grain production and the market prices of grain. We find that agricultural subsidies greatly promoted an increase in demand for the input factors of agricultural production and further that input prices may have been pushed up. Table 3 exhibits dramatic increases in average usages of pesticides, fertilizer, and diesel in agriculture before and after the implementation of the subsidy policies. During the 9-year period from 1997 to 2003, prior to the introduction of China's subsidy policies for agriculture, the average usages per year of pesticides, fertilizer, and diesel were 1.2, 40.8, and 13.4 million tons, respectively; however, from 2004 to 2012, when the subsidy policies were implemented, the average usages increased to 1.6, 52.4 , and 19.5 million tons, a jump of $33.3 \%, 28.4 \%$, and $45.5 \%$, respectively. The demand for basic inputs to agricultural production appeared to have been greatly stimulated by these agricultural support policies, especially for

Table 3. Changes in the average annual usage of basic inputs in agricultural production (million tons)

\begin{tabular}{cccc}
\hline Factor & Average (95-03) & Average (04-12) & Change (\%) \\
\hline Pesticide & 1.2 & 1.6 & 33.3 \\
Fertilizer & 40.8 & 52.4 & 28.4 \\
Diesel & 13.4 & $19.5^{*}$ & 45.5
\end{tabular}

Source: China Agricultural Development Report 2010, China Statistical Yearbook 2013. Note: the value with * is averaged from 2004 to 2011 due to the data in 2012 is unavailable. diesel, whose consumption increased by approximately $50 \%$.

The dramatic increases in input factor demand may have caused factor prices to increase. Table 4 shows the changes in factor prices, rice production costs, and rice prices. From 2000 to 2002, input factor prices did not show significant changes; but since 2003, considerable increases have been observed in the prices of fertilizer and oil, which are the two most important factors in grain production and which occupy the largest share of total production costs. From 2003 to 2012, the prices of fertilizer and oil increased by approximately $93.5 \%$ and $95.5 \%$, respectively. The prices of pesticides and machinery remained stable, even after the subsidy policies, because of their small share in total production costs. Increasing input prices raised grain production costs. In the case of rice, its production costs remained low at approximately 40 yuan/50 kg from 2000 to 2002; but from 2003, they started to increase annually. In 2012, the costs reached a high level of 90.6 yuan $/ 50 \mathrm{~kg}$, more than twice that in 2003.

As a result of increasing production costs caused by the subsidies, grain prices were pushed up. In the case of rice, its prices also experienced significant increases. In 2003, rice prices started to increase from 51.4 yuan $/ 50 \mathrm{~kg}$ in 2002 to 60.1 yuan $/ 50 \mathrm{~kg}$, an increase of $16.9 \%$. In 2004, when the minimum purchasing price policy for rice was implemented, rice prices increased to 79.8 yuan $/ 50 \mathrm{~kg}, 32.8 \%$ higher than that in 2003 . After 2004, under the mixed influences of the subsidy policies and the price support policy, rice prices continued to increase at an annual rate of $6.7 \%$ (Table 4 ).

Most of the subsidies are actually direct payments. They are paid to farmers together with all types of subsidies, and farmers can use them without constraints. Hence, subsidies stimulate input demand via their income effect. Figure 2 illustrates the mechanism through which

Table 4. Changes in factor prices, rice production costs, and rice producer prices

\begin{tabular}{|c|c|c|c|c|c|c|}
\hline Year & $\begin{array}{l}\text { Machinery } \\
\text { (Index) }\end{array}$ & $\begin{array}{l}\text { Pesticide } \\
\text { (Index) }\end{array}$ & $\begin{array}{l}\text { Fertilizer } \\
\text { (Index) }\end{array}$ & $\begin{array}{c}\text { Oil } \\
\text { (Index) }\end{array}$ & $\begin{array}{l}\text { Production costs } \\
\quad(¥ / 50 \mathrm{~kg})\end{array}$ & $\begin{array}{c}\text { Rice } \\
(¥ / 50 \mathrm{~kg})\end{array}$ \\
\hline 2000 & 125.6 & 117.5 & 165.5 & 170.7 & 40.3 & 51.7 \\
\hline 2001 & 122.0 & 114.1 & 162.0 & 170.7 & 39.3 & 53.7 \\
\hline 2002 & 118.2 & 111.8 & 165.9 & 168.8 & 40.8 & 51.4 \\
\hline 2003 & 116.4 & 111.7 & 168.5 & 182.0 & 42.1 & 60.1 \\
\hline 2004 & 119.0 & 115.1 & 190.1 & 197.3 & 42.9 & 79.8 \\
\hline 2005 & 121.7 & 119.8 & 214.4 & 219.2 & 48.3 & 77.7 \\
\hline 2006 & 123.6 & 121.7 & 214.7 & 248.6 & 49.4 & 80.6 \\
\hline 2007 & 125.7 & 123.4 & 221.9 & 261.8 & 51.1 & 85.2 \\
\hline 2008 & 137.0 & 133.3 & 292.3 & 296.0 & 58.7 & 95.1 \\
\hline 2009 & 138.2 & 133.4 & 273.9 & 279.5 & 59.5 & 99.1 \\
\hline 2010 & 140.1 & 133.9 & 269.9 & 308.2 & 68.5 & 118.0 \\
\hline 2011 & 146.6 & 137.4 & 305.8 & 341.5 & 78.2 & 134.5 \\
\hline 2012 & 149.7 & 140.7 & 326.0 & 355.9 & 90.6 & 138.1 \\
\hline
\end{tabular}

Source: China Statistical Yearbook 2004-2013; China Agricultural Development Report 2004-2013.

Note: for the index prices with a base year of 1990(100). 
the agricultural subsidies impact the factor markets through their income effect. The top figure is an incomeconsumption curve of farmers for agricultural input factors. As farmers, especially poor farmers who rely on agricultural production as a major source of income, obtain subsidies or subsidy amounts that are increased, their incomes also increase from level 1 to level 2, and they can buy more inputs for production. The quantity of the inputs they buy, $X_{1}$, is increased from $Q_{1}$ to $Q_{2}$. This means that the input factor demand is increased, the factor demand curve shifts from $\mathrm{D}_{1}$ to $\mathrm{D}_{2}$, and the factor price increases from $\mathrm{P}_{1}$ to $\mathrm{P}_{2}$. Finally, the factor supply and demand markets achieve a new equilibrium at $\mathrm{E}_{2}$.

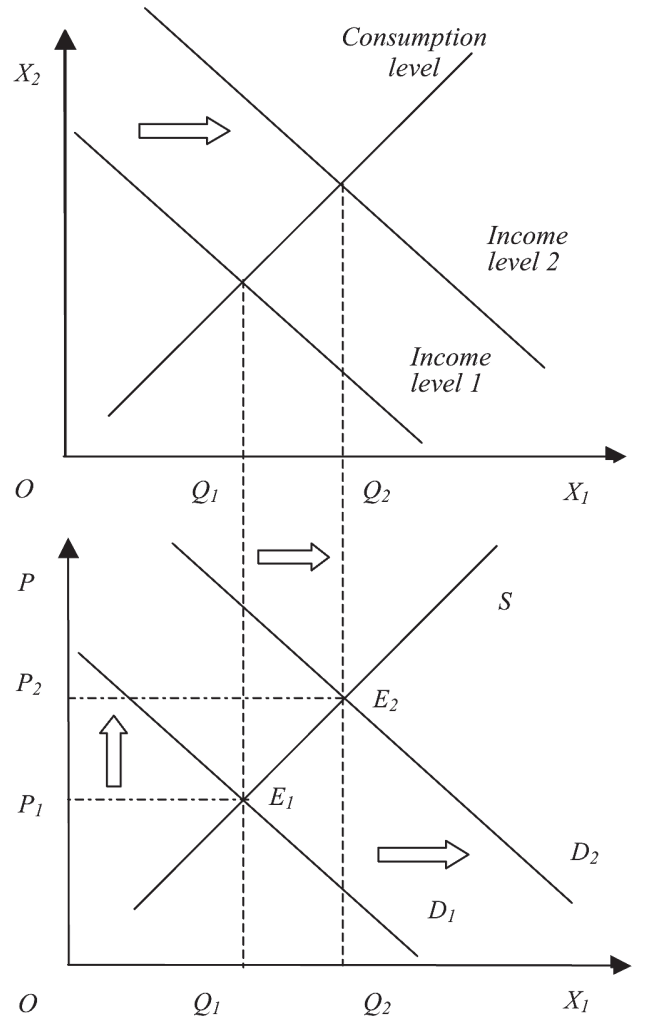

Fig. 2. Agricultural subsidies and changes in factor markets.

In summary, because of the extensive government interventions in the grain markets, the extra grain supply in the market was purchased by the government so as to support grain prices. As a result, the subsidies barely had noticeably negative impacts on grain prices, despite the increased grain supply that resulted from the subsidies. But they did result in significant increases in agricultural input prices and grain production costs. Consequently, subsidies may show positive impacts on grain market prices as a whole through the increased input prices and grain production costs. In the next section, we attempt to evaluate these impacts using econometric techniques.

\section{METHODOLOGY AND DATA}

An autoregressive distributed lag (ARDL) model is employed to further evaluate the impacts of agricultural subsidies on market prices for rice, wheat, and corn. For the subsidy variable, although the Chinese government provides subsidies for different purposes, all the subsidies are paid directly and collectively to farmers, and the farmers are free to use them for the production of any grain. Hence, we combine the subsidies to construct a single subsidy variable as a proxy for the scale of the subsidies. For a small sample size, the number of explanatory variables should not be large. Thus, only oneyear-lagged variables are incorporated into the model. The specification of the ARDL model is shown as follows:

$$
\ln P_{i t}=C+\beta_{1} \ln P_{i t-1}+\beta_{2} \ln S_{t}+\beta_{3} \ln S_{t-1}+u_{i t}
$$

where $P$ indicates grain producer prices; $S$ is the total amount of agricultural subsidies; $i$ presents rice, wheat, and corn; $t$ is the year; $u$ is the error term; and $\beta_{1}, \beta_{2}$, and $\beta_{3}$ are parameters need to be estimated. The sum of $\beta_{2}$ and $\beta_{3}$ reflects the overall impact of the subsidy policies on grain prices (Hill et al., 2010). As discussed in the previous section, the subsidies may show positive impacts on market prices for grain. Thus, the sum of $\beta_{2}$ and $\beta_{3}$ is expected to take a positive sign. For data, grain prices are obtained from the China Yearbook of Cost and Return of Agricultural Commodities; agricultural subsidy amounts are collected from the China Agricultural Development Report. All the data are in a natural logarithm format. The study period is from 2003 to 2012 .

\section{ESTIMATED RESULTS}

In the corn-price model, a dummy variable with a value of 1 for 2008 and 0 otherwise is included to adjust to the relatively large price increases that occurred in 2008. There exists the same factors which influence the dependent variable, grain prices, in each equation, but they have not included in the equations. This may result in the error terms in the different price models, at the same point in time, are correlated. Therefore, the seemingly unrelated regression (SUR) technique is employed to account for the contemporaneous correlations among the error terms of the three equations (Hill et al., 2010). The estimated results using the SUR technique are listed in Table 5. Generally, these joint estimates are better than separate least squares estimates. We also report the estimates obtained using ordinary least regression (OLS) in Table 6 so as to make a comparison with the SUR estimates.

Through the comparison, we find that the standard errors of the SUR estimates are lower and the significance levels are higher than those of the OLS estimates, indicating that by using the SUR technique, the estimation has been improved. Although the sample size is small, the models fit the data quite well. The R-squared values are very high at $0.95,0.98$, and 0.98 for the rice-, wheat-, and corn-price models, respectively. This indicates that the independent variables explain most of the variations in the dependent variables. Most variables are significant at a $1 \%$ significance level. LM(1) indicates a 
Table 5. SUR estimates of grain price equations

\begin{tabular}{|c|c|c|c|c|c|c|}
\hline \multirow{2}{*}{ Variable } & \multicolumn{2}{|c|}{ Rice } & \multicolumn{2}{|c|}{ Wheat } & \multicolumn{2}{|c|}{ Corn } \\
\hline & Coefficient & Std. Error & Coefficient & Std. Error & Coefficient & Std. Error \\
\hline Constant & 0.120 & 0.509 & $0.544^{*}$ & 0.300 & $1.238 * * *$ & 0.304 \\
\hline$P_{t-1}$ & $0.872 * * *$ & 0.143 & $0.742 * * *$ & 0.082 & $0.461 * * *$ & 0.106 \\
\hline$S$ & $0.153^{* * * *}$ & 0.039 & $0.171^{* * *}$ & 0.016 & $0.209 * * *$ & 0.036 \\
\hline$S_{t-1}$ & $-0.076 * * *$ & 0.019 & $-0.077^{* * *}$ & 0.009 & $-0.029 * *$ & 0.012 \\
\hline$D M$ & - & - & - & - & $-0.221 * * *$ & 0.029 \\
\hline $\mathbf{R}^{2}$ & 0.95 & & 0.98 & & 0.98 & \\
\hline $\operatorname{LM}(1)$ & 0.68 & & 0.97 & & 0.23 & \\
\hline
\end{tabular}

Note: $* * * * *, *$ indicate $1 \%, 5 \%$ and $10 \%$ significance level, respectively.

Table 6. OLS estimates of grain price equations

\begin{tabular}{|c|c|c|c|c|c|c|}
\hline \multirow{2}{*}{ Variable } & \multicolumn{2}{|c|}{ Rice } & \multicolumn{2}{|c|}{ Wheat } & \multicolumn{2}{|c|}{ Corn } \\
\hline & Coefficient & Std. Error & Coefficient & Std. Error & Coefficient & Std. Error \\
\hline Constant & 0.087 & 0.670 & 0.385 & 0.410 & $1.024^{* *}$ & 0.477 \\
\hline$P_{t-1}$ & $0.882^{* * * *}$ & 0.197 & $0.786^{* * * *}$ & 0.113 & $0.547 * * *$ & 0.169 \\
\hline$S$ & $0.152 * *$ & 0.053 & $0.168 * * *$ & 0.022 & $0.182^{* * * *}$ & 0.057 \\
\hline$S_{t-1}$ & $-0.076^{* * * *}$ & 0.025 & $-0.080^{* * * *}$ & 0.012 & -0.027 & 0.017 \\
\hline$D M$ & - & - & - & - & $-0.191 * * *$ & 0.053 \\
\hline $\mathbf{R}^{2}$ & 0.95 & & 0.98 & & 0.98 & \\
\hline $\mathbf{L M}(1)$ & 0.93 & & 0.86 & & 0.96 & \\
\hline
\end{tabular}

Note: $* * * * *, *$ indicate $1 \%, 5 \%$ and $10 \%$ significance level, respectively.

statistical probability of the first order lagranger multiplier test. The results fail to reject the null hypothesis of the test, providing indication of no serial correlation in the regressions.

For the subsidy variables, both the subsidy variable and the one-year-lagged variable are highly significant at either the $1 \%$ or $5 \%$ significance level in each model, indicating that subsidies show marked impacts on grain prices. For rice, the coefficient of the subsidy variable in the current year is 0.153 and that for the one-yearlagged subsidy is -0.076 . Thus, the overall elasticity of rice prices, with respect to agricultural subsidies, is 0.077 . Likewise, the overall elasticities of wheat and corn prices are 0.094 and 0.180 , respectively. This implies that a $1 \%$ increase in total subsidy amounts may result in a $0.077 \%$, $0.094 \%$, and $0.180 \%$ increase in rice, wheat, and corn prices, respectively (Table 5).

\section{CONCLUSION}

In this study, we have discussed the relationship between agricultural subsidy policies and grain market prices in the context of government interventions in grain markets and the direct-payment schemes of the subsidy policies. Because of the extensive government interventions in grain markets, the extra supply in the market was purchased by the government in terms of the grain minimum purchasing price policy. Moreover, according
Table 7. Elasticities of grain prices with respect to agricultural subsidies

\begin{tabular}{ccc}
\hline Rice price & Wheat price & Corn price \\
\hline 0.077 & 0.094 & 0.180 \\
\hline
\end{tabular}

Source: Authors' Calculation.

to the causality test results, grain production may not be a cause of the changes in grain market prices. This implies that increasing grain production may not have negative influences on grain market prices, and thus, the subsidies can hardly show negative impacts on grain prices through increasing grain supply. While the large scale of agricultural subsidies has triggered dramatic increases in input demand through the income effects of the direct subsidy payments, the increased demand for agricultural inputs has caused the prices of these inputs to increase. Further, these increasing input prices may have a positive impact of subsidies in that they ultimately result in an increase in grain prices.

Based on the theoretical analysis, the ARDL models are constructed to examine the impacts of agricultural subsidies on grain prices. In the price models for each grain type, the subsidy variables are highly significant, and the general influences of the subsidies are positive. This suggests that the agricultural subsidy policies may have contributed to the increases in the market prices of 
grain. Statistically, the overall elasticities of the prices of rice, wheat, and corn are 0.077, 0.094, and 0.180, respectively. Although they are relatively small, considering the sharp increases in the amount of total subsidies, the impact of the subsidy policies on grain market prices is not small. The Chinese government provides a large amount of subsidies to support agricultural development. These subsidies show positive rather than negative impacts on grain market prices under the existing pattern of subsidy payments and the political intervention of the Chinese government.

\section{REFERENCES}

Chen, H. L. Wu and Y. Wang 2010 Impacts of subsidy policy on grain production in China, Journal of Agrotechnical Economics, 4: 100-106

Department of Prices of the National Development and Reform Commission, China Yearbook of Cost and Return of Agricultural Commodities (various issues), China Statistics Press, Beijing (China).

Granger, C. W. J. 1980 Testing for causality, Joumal of Economic Dynamics and Control, 2: 329-352

Granger, C. W. J. 1988 Causality, cointegration, and control, Joumal of Economic Dynamics and Control, 12(2): 551-559

Hill, R. C., W. E. Griffiths and G. C. Lim 2010 Principles of Econometrics, $4^{\text {th }}$ ed. John Wiley \& Sons, Hoboken (USA) pp. $566-570$

Huang, J., X. Wang, H. Zhi and Z. Huang 2011 Impacts of grain direct subsidy and comprehensive subsidy on agricultural production, Journal of Agrotechnical Economics, 1: 4-12

Jiang, H. and Z. Wu 2009 Effects of grain subsidy policy in Miluo city Hunan province, Issues in Agricultural Economy, 11: 28-32

Li, G. 2011a Economic analysis on increasing agricultural product prices in China, Expanding Horizons, 1: 19-21

Li, G. 2011b Analysis on increases in agricultural product prices since 2003 in China, Chinese Rural Economy, 2: 11-21

Li, G. 2013 Two-side effects of grain subsidy on grain prices, Grain News, July 11

Liu, K. 2010 Impacts of grain direct subsidy policy on farmers' decision behaviors of grain planting, Chinese Rural Economy, 2: $12-21$

Ministry of Agriculture, China Agricultural Development Report (various issues), China Agriculture Press, Beijing (China).

$\mathrm{Mu}, \mathrm{Y}$. and A. Koike 2009 SCGE model construction and simulation analysis of the agricultural subsidy policy in China, Journal of Quantitative \& Technical Economics, 1: 3-14

National Bureau of Statistics, China Statistical Yearbook (various issues). China Statistics Press. Beijing (China).

Qian, J., S. Ito, Y. Mu and H. Isoda 2013 Impact of agricultural subsidies on rice price in China: a cointegration analysis," Journal of Rural Problems, $\mathbf{4 9}(1)$ : 172-176

Robert S. P. and L. R. Daniel 1998 Econometric Models and Economic Forecasts, $4^{\text {th }}$ ed. China Machine Press, Beijing (China) pp. 242-245

Sims, C. A. 1972 Money, income and causality, The American Economic Review, 62(4): 540-552

Wang, J. and H. Xiao 2006 Evaluation of effect of grain direct subsidy policy in China, Chinese Rural Economy, 12: 4-12

Wang, J. and H. Xiao 2007 Policy effects of fine seed subsidy, farm machinery subsidy and agricultural tax elimination in China, Issues in Agricultural Economy, 2: 24-28

Zhou, Y., W. Zhao and X. Zhang 2009 Evaluation on China's recent domestic agriculture support policies, Issues in Agricultural Economy, 5: 4-11 